NBER WORKING PAPER SERIES

\author{
INVESTMENT IN FIXED AND WORITIG CAPTTAL \\ DURING EARLY INDUSTRIAITZATTON: \\ EVIDENCE FROM U.S. MANUFACTURING FIRMS
}

\author{
Kenneth L. Sokoloff
}

Working Paper No. 1385

\author{
NATIONAL BUREAU OF ECONOMIC RESEARCH \\ 1050 Massachusetts Avenue \\ Cambridge, MA 02138 \\ June 1984
}

The author is grateful to Stuart Bruchey, Paul David, Stanley Engerman, Robert Fogel, Claudia Goldin, and Robert Margo for their comments and criticisms. He would also like to thank Susan Einstein for her expert research assistance. The research was supported by the UCLA Academic Senate. The research reported here is part of the NBER's research program in Development of the American Economy and project in Productivity (World Economy). Any opinions expressed are those of the author and not those of the National Bureau of Economic Research. 
NBER Working Paper 非1385

June 1984

\author{
Investment in Fixed and Working Capital \\ During Early Industrialization: Eyidence \\ From U, $S_{*}$ Manufaccuring Firms
}

\begin{abstract}
ABSTRACI
This paper utilizes a survey of the U.S. manufacturing firms from 1832 to investigate the structure of manufacturing investment during early industrialization. Although several manufacturing industries, such as cotton textiles, depart from the pattern, most appear to have devoted the bulk of their investments to working capital. This variation across industries in the composition of capital investments is indicative of a more general variation in factor intensities, and bears on the issues of why industries became concentrated in the regions they did, and the degrees to which they were adversely affected by the limited availability of longmern loans. Evidence that most manufacturing industries had quite modest investments in machinery and tools per unit of labor is also presented, serving to undercut the notion that the early period of industrialization was based on a proliferation of new, machinery-intensive technologies.
\end{abstract}

\footnotetext{
Kenneth L. Sokoloff Department of Economics University of California Los Angeles, CA 90024 (213) $825-4249$
} 
Economic historlans have long been concerned w1th the absolute and relative amounts of 1nvestment by manufacturers 1 in flxed and working capital during the early stages of Industrialization. The question that has, perhaps, most directly attracted them to the subject has been how closely industrial development was related to the introduction of sophisticated machinery and production processes that were highly intensive in fixed capital. It has also been argued, however, that the division of investment between f1xed and working (or clrculating) capltal has an 1mportant bearing on the 1ssue of the extent to which industrial expansion might have been impeded by the organization of financlal markets. ${ }^{1}$ Pollard, in particular, suggested that the bulk of Investment in early manufacturing took the form of clrculating capltal, and that the growth of this sector was accordingly not substantially hindered by $11 \mathrm{~m} 1 \mathrm{ted}$ access to sources of long-term credit. ${ }^{2}$ In his view, merchants and other traditional suppliers of short-term credit could finance the working capital, which was relatively liquid and turned over rapidly, leaving only a modest share of manufacturing investment to be raised through equity and long-term loans.

Most scholars who have studied the division of investment in manufacturing between flxed and working capital have had to rely predominantly on the Individual records of firms. Although such bodies of evidence are rich and detalled, the cost of retrieving them is high, and has restricted 1nvest1gators to the experiences of a relatively small number of establishments. A recently collected sample from the 1832 McLane Report, however, contalns Information for a large cross-section of northeastern firms on the composition of the1r cap1tal 1nvestments. 3 The U.S. Treasury Department survey of manufactures, from which these data were drawn, was marred by several defects, such as variation across geographic areas in the quality of coverage and the 
format of the questionnalre administered. Nevertheless, the 1194 f1rms included in the sample encompass a broad spectrum of manufacturing industries, establishment sizes, and locations. Careful analysis of this body of evidence can yield much insight 1nto the operations of manufacturing firms and financial markets during the initial phase of industrialization in the U.S. One of the problems associated with employing the McLane Report data is that the categorles used by enumerators to decompose investment do not always conform to modern concepts of what constitutes fixed and working capital, and their various subcomponents. An already alluded to difficulty of this sort is that firms In Rhode Is land, New Hampshire, and the Middle Atlantic states were surveyed with a different questionnalre than were those in Massachusetts, Ma1ne, Vermont, and Connecticut. Establishments from the former set of states (henceforth referred to as Group I) decomposed their capital investments into two components, "capital invested in ground and bulldings, and water power, and in machinery" and the "average amount in materials, and in cash for the purchase of materials, and payment of wages." Those from the latter areas (Group II) distinguished between the "value of real estate, buildings, and fixtures, occupled and used for the business," the "value of tools, machinery, and apparatus other than the fixtures," and the "value of average stock on hand, and in the process of manufacture." Thus, all enumerators for the 1832 survey appear to have been operating with simflar instructions as to what sorts of flxed assets should be classifled together, although those working with Group II firms provided more detall by dividing such assets 1nto two classes. Their understanding of fixed capital resembles the modern one, and evidence seems to support the view that their measure of the former was a good approximation of the latter. 4 
As for the treatment of working capital, enumerators appear to have only surveyed firms on the value of their inventories, and omitted the other major component of this type of capital, accounts recelvable or the credit extended to customers. 5 Fortunately, additional information reported by most of the Group II establishments surveyed allows this important component of working capital to be estimated at the firm level. About 300 establishments revealed the proportions of their output sold for cash, for credit, or for barter, and If for credit, at what average term. By fitting regressions with the proportion of output sold on credit and the average terw of credit as the dependent variables over the data for the reporting firms, predicted values of the varlables were generated for the other observations. Under the assumption that the manufacturing establishments had been maintaining constant levels of output and credit extension, firm-level estimates of the average accounts recelvable were computed from the following expression:

$$
\mathrm{AR}=(\mathrm{PC} \cdot \mathrm{Q})(\mathrm{T} / 12)
$$

where $A R$ is accounts recelvable, $P C$ is the proportion of output sold on credit, $Q$ is the value of annual output, and $T$ is the average term (in months) of the credit extended. Given that the levels of production and sales are likely to have varled seasonally, the average accounts recelvable estimated by this procedure, as well as the average level of inventories reported by firms, may be significantly different from the actual monthly investments made in these components of working capital. Whether, and how, this variation around the mean should influence the interpretation of the quantitative results is unclear, and remalns to be determined. Seasonality might also affect the estimated patterns by encouraging 1nvestment in working capital, relative to that in fixed capital. 
The percentages of the total investment accounted for by the various categorles of capital have been calculated for selected industries from the 1832 sample, and are presented, by group, in Table 1. Also reported for the Group II establishments are estimates of the total capital investment per equivalent worker and of the investment in tools and machinery per equivalent worker. The results suggest that working capital attracted a substantial share of the investments made by manufacturing firms. When credit extended to customers (accounts recelvable) is included in the estimate of the total capital Investment, the working cap1tal share ranges between 40.6 and 65.6 percent across the $\mathrm{s} 1 \mathrm{x}$ Group I Industries, and between 37.6 and 88.7 percent across the eight in Group II. 6 The significance of these figures is buttressed by the recognition that the relative importance of working capital would be understated if some firms reported the gross value of their capital stock, rather than the net value.

One of the most interesting features of these estimates is the covariation across industries of the working capital share with the level of total capital per unit of labor. The three most capital-intensive industries, such as cotton textiles, wool textiles, and paper, have relatively low working capital shares, between 37.6 and 53.3 percent among the Group II firms. WorkIng capital accounts for higher proportions of the total investment in the other Industries, between 53.6 and 88.7 percent among the same group of establishments. The sizes of individual establishments also vary between the two classes of industries, with the average plants in the more capitalIntensive Industries (especially textiles) belng much larger than those from the latter group.7 Thus, the evidence seems to favor distinguishing between manufacturing industries with respect to their demand for long-term capital. Firms in highly capital-intensive industries such as textiles are likely to 


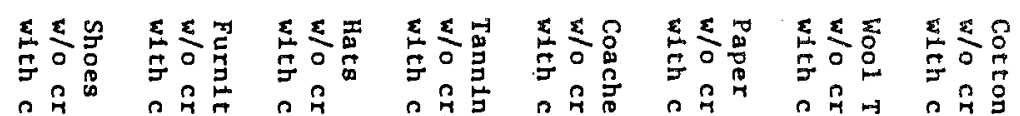

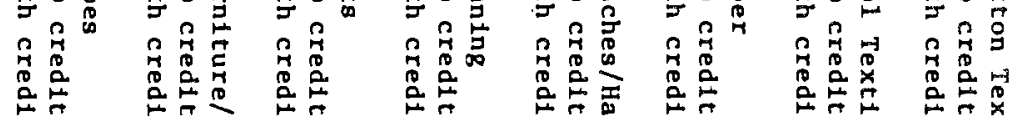

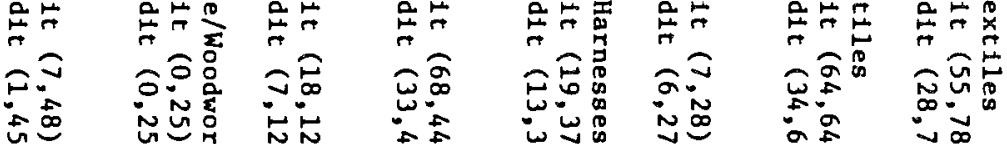

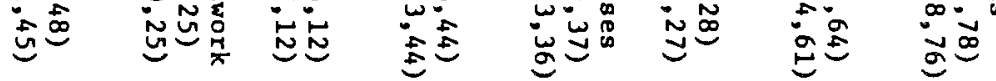

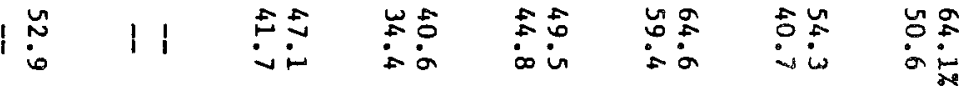

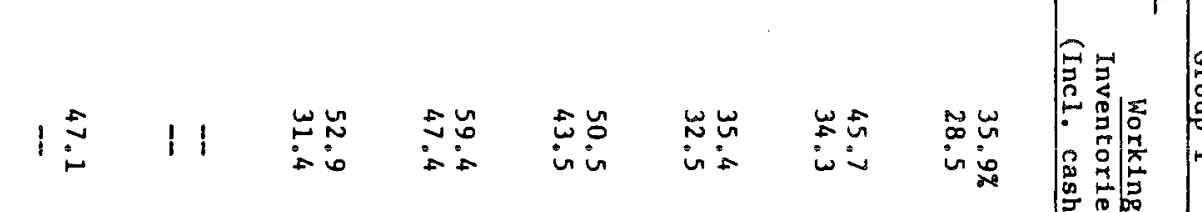

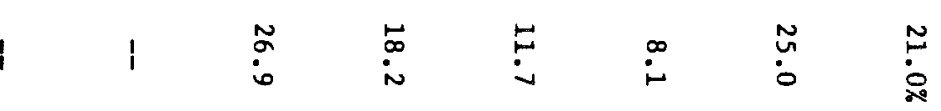

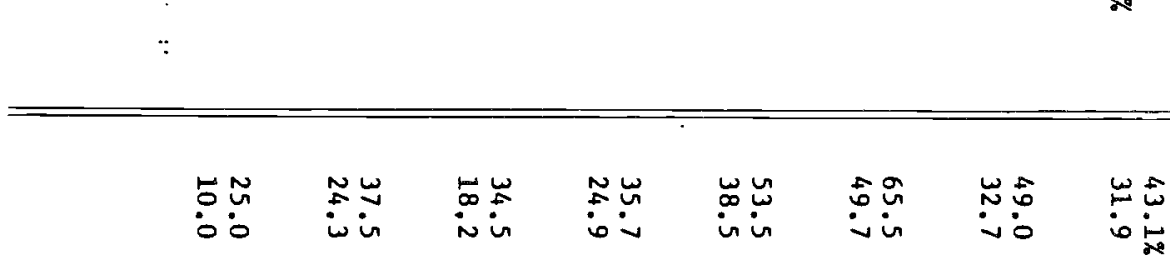

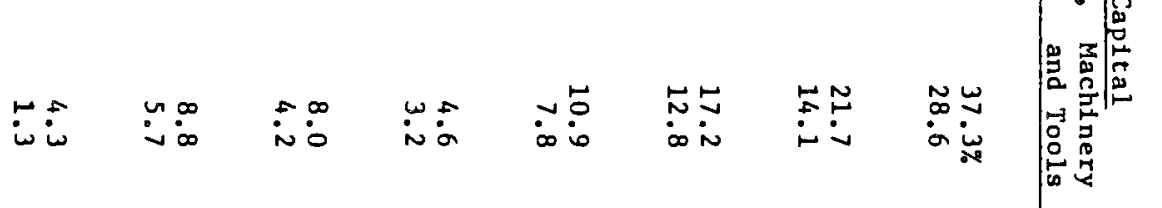
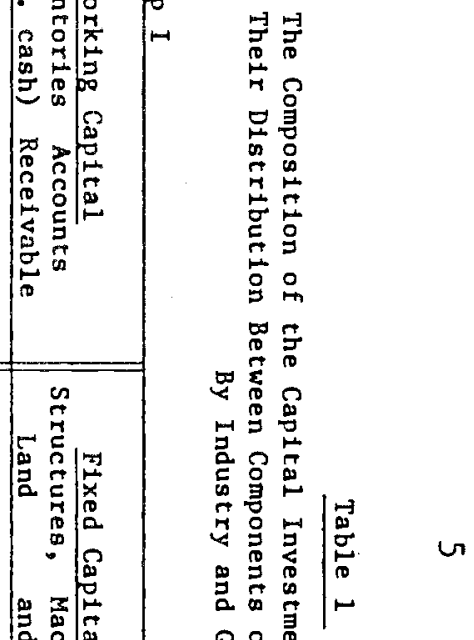

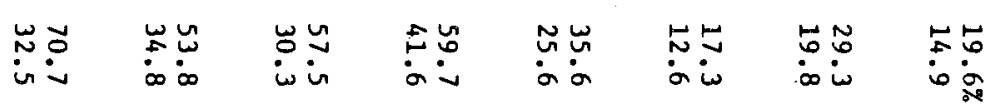

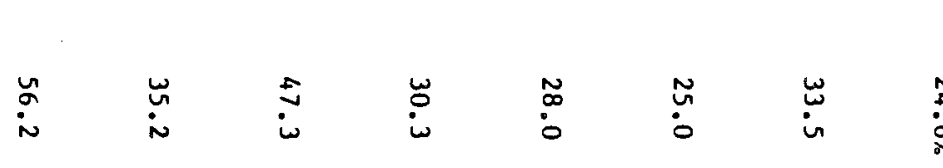

$\overline{1}$

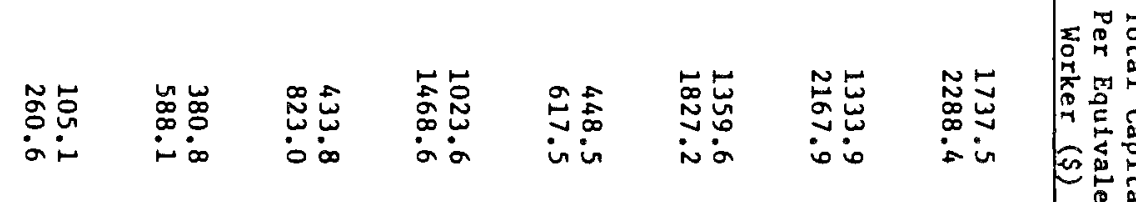




\section{Notes and Sources:}

These estimates are welghted averages computed over all of the firms in the 1832 sample that supplied the relevant Information, with the exceptions of firms that reported no investment in structures and land, no investment in machinery and tools (a requirement which excludes a number of putting-out enterprises in shoes), or operating fewer than seven months a year. The principal criteria for including industries in this table were a sufficient number of observations and a relatively homogeneous set of outputs. The Industries are ordered by the value of machinery and tools per equivalent worker. The number of equivalent workers is equal to the sum of the number of adult male employees, four-tenths times the number of female and child employees, and 1 (representing the entrepreneur's labor input). The figures within parentheses represent the numbers of observations of Group I and Group II firms over which the estimates on the respective lines were computed. The numbers of observations differ between those estimates computed with and those without credit, because some firms did not report the value of their output. The estimated values of the proportion of output sold on credit and the average term of credit were computed from regressions fitted over those observations that reported on these variables. Included as independent variables in these regressions were the $\log$ of the number of employees and Industry dummy variables. 
have had greater relative, and much greater absolute, demands for long-term funds than their counterparts in other industries, because on average a greater share of their investment went to fixed capital, more investment capital was utflized for each unit of their labor, and more units of labor were employed by them. Pollard's claim that manufacturers durting early industrialization were less dependent on supplies of long-term capital than has generally been recognized might apply in the U.S. case to textiles. It seems, however, to more accurately characterize other 1ndustries. Another 1uplication of the data on Group II firms is that, with the exception of cotton textiles, the capital invested in machinery and tools amounted to only a small fraction of the total investment. 8 In all other Industries, the value of the buildings, land, and fixtures far outweighed that of machinery and tools. Although machinery and tools attracted nearly 30 percent of the capital invested by the cotton textile establishments, one cannot fall to be impressed by the relative insignificance of this category of Investment when the second-most mechanized Industry, wool textlles, barely manages a 14 percent share. The industry-specific estimates of the value of machinery and tools per equivalent worker lend further support to this judgment. The figure for cotton textiles is $\$ 656.4$, more than twice as large as that for wool textiles, and more than ten times the figures for coaches/ harnesses, tanning, hats, furniture/woodwork, and shoes. All of the latter average less than $\$ 50$ of machinery and tools per equivalent worker.

Although the industry averages reported in Table 1 are quite 1nformative, they don't provide insight into how the composition of investment capital varied with firm characteristics such as size and location. Hence, the Implications drawn from them might not apply to all classes of establishments within the industries in question. Regressions with the various components of 
the total investment (here treated as the sum of fixed capital and Inventories) per unit of labor, and the proportions of the investment accounted for by those components, as the dependent variables were accordingly estimated over the Group II firms, and are presented in Table 2.9 The first four regressions suggest that the total capital investment, and each of 1 ts major subcomponents, Increased relative to the labor input with the firm scale of production in all manufacturing Industries examined except shoes. Perhaps more surprising is that, In industries other than textiles, the share of the capital investment allocated to fixed capital decreased with establishment size, as did the amount of investment in machinery and tools relative to that In Inventories. The fixed capital share of a firm's investment also decreased with the degree of urbanization in the county in which the firm was located. Thus, in most industries, the larger firms employed greater amounts of fixed capital per unit of labor than their smaller competitors, but they were even more extensive users, both relatively and absolutely, of inventories and working capital in general. 10

These regressions appear to support and extend the interpretations drawn from the 1ndustry-specific averages. Not only were the proportions of the firm Investments in inventories quite large in industries other than textiles, but they were especially so in the larger firms whose development has often been linked to industrialization. What explains this observed relationship between the composition of the capital investment and the size of firms? There are a number of hypotheses but the evidence does not allow us to clearly distinguish between them. One possibility is that larger firms enjoyed, on average, lower-cost access to short-term credit than did small establishments, and were therefore led to invest relatively more in working capital. They might have attracted more favorable terms by trading with merchants who 


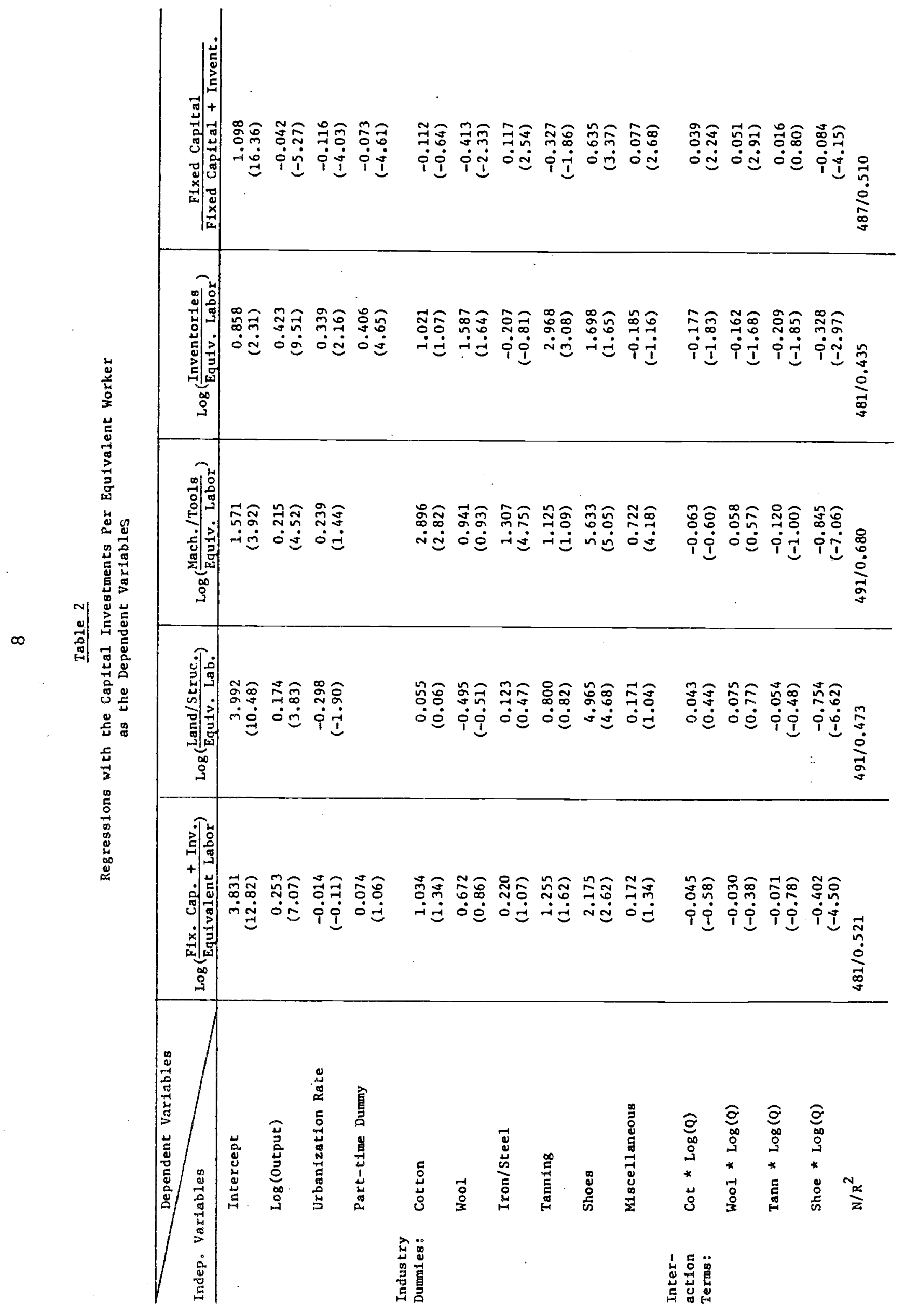


Notes and Sources

These regressions were estimated over all of the Group II firms in the 1832 sample that supplied the relevant information, with the exceptions of firms that reported no investment in structures and land, no investment in machinery and tools, or operating fewer than seven months a year. The t-statistics appear within parentheses below the corresponding regression coefficients. The "urbanization rate" variable is defined for the county in which the firm was located as the proportion of the population in 1830 that resided in cities of 2500 or more people. The "part-time dumm" is set equal to 0 for those firms that reported operating at least 11 months a year. The dummy is set to 1 for all other firms. Since many establishments falled to Indicate what portion of the year they operated, this variable seems likely to suffer from a significant measurement error. 
supplied funds to their regular contacts, belng easier to monttor, or being less risky borrowers. Another theory is that larger firms had a relatively greater demand for worklng capltal, perhaps because they were more risk averse about running out of inventorles and being compelled to shut down, or found it advantageous to hold larger stocks of inventories and offer more credit when dealing in greater quantities and with more distant customers.

A third response to the statistical finding might be to label it an artifact. Since manufacturing establishments don't always operate at full capac1ty, and working capltal is more directly related to current output levels than fixed capital, one would generally expect to observe some positive correlation between the current output of f1rms and their ratio of working to fixed capital. This effect does not seem to provide an adequate explanation of the regression results, however, because the labor input is also closely linked to current output, and thus the same logic would predict an increase in the ratio of labor to fixed capital with firm size, rather than the estimated decrease.

A final piece of evidence that bears on the 1ssues of whether and why the working capital increased with firm size is provided by firm data on the extension of credit. Regressions were estimated with the proportion of output sold on credit as the dependent varlable. One of these is presented below without the industry dummies, which were jointly insignificant.

$$
\begin{aligned}
& \text { Proportion of Output Sold on Credit = } \\
& \text { Intercept } \quad 0.778(5.49) \\
& \log (\text { \# of employees) } \quad-0.012(-0.31) \\
& \text { Urbanization Rate } \quad-0.569(-1.92) \\
& \text { Proportion of } \\
& \text { Output Sold Locally }-0.252(-3.44)
\end{aligned}
$$


Interaction between

$$
\begin{aligned}
& \text { Urbanization and } \\
& \text { Log (\# of employees) } 0.199(2.38) \\
& \mathrm{N}=224 \\
& \mathrm{R}^{2}=0.325
\end{aligned}
$$

This regression conforms well with the view that the utilization of working capital grew disproportionately with the size of $\mathrm{f} 1 \mathrm{rm}$, and lends some support to each of the hypotheses concerned with that pattern. The negative coefficient on the proportion of output sold locally may indicate that as firms expanded to serve broader markets, they were driven to extend more credit (demand more working capital) in order, perhaps, to compete more successfully for buyers who preferred to delay payment unt1l after delivery. Alternatively, the sign on the coefficlent could arise from those firms that sold outside the local areas having cheaper access to short-term credit, through the merchants and other substantial traders that they presumably dealt with more frequently. The positive relationship between size of firm and the proportion sold on credit, particularly strong in urban counties, also seems consistent with each of the theories. Larger firms might be expected to have both been Involved in disproportionately more of the large-bloc transactions that tend to be carried out on credit rather than in cash, and faced lower credit costs. Urbanization appears to have been assoclated with a decrease in the proportion of output sold on credit among small firms, but an increase among large establishments. This pattern might be attributable to firms in rural areas knowing more about their individual customers (consumers of product) that bought directly from them than did their counterparts in the c1ty. For the larger firms, the greater the degree of urbanization in the county, the greater the probability that they would be dealing with merchants or other established middlemen that were more likely to provide short-term 
loans and delay payment for goods. 10

Conclusions

Th1s paper has sought to document the general quantitative importance of manufacturing investment in working capital during the early stages of U.S. Industrialization. Another objective has been to emphasize the sharp variation across industries in the composition of their capital investments, and more generally, in the factor intensities of their operations. In particular, some major Industries of the era, such as cotton textiles, wool textiles, and paper, seem to have been relatively intensive in fixed capital, while most of the others appear to have been intensive in working capital or labor. The difference in capital requirements between the two classes of industries is of special interest here, because of 1 ts implications for understanding why certain industries became concentrated in the areas and regions they did, and the degrees to which they were adversely affected by the limited avallability of long-term loans. Cotton textile firms, for example, may have tended to cluster in New England, because that region's developed financlal markets and Institutions provided long-term capital at lower cost. Manufacturers of hats and shoes, however, would have tended toward areas where short-term credit and the desired classes of workers were relatively abundant. 11

The other major argument of this paper has been that most of the manufacturing industries examined had quite modest investments in machinery and tools per unit of labor. Although the value of this ratio tended to increase with firm size, the evidence serves to undercut the notion that the early period of Industrialization was based on a proliferation of new, machinery-1ntensive technologies. On the contrary, the general dominance of the working capital share of investment, as well as 1ts positive association 
with firm size, seems to suggest that the expansion of markets may have played the principal role in spurring Industrial development. 
FOOTNOTES

${ }^{1}$ Sidney Pollard, "Fixed Capital in the Industrial Revolution in Britain," this Journal, 24 (September 1964).

${ }^{2}$ Cotton textiles appears to have been the only manufacturing industry to have drawn significantly on long-term loans during the period. See Lance E. Davis, "Sources of Industrial Finance: The American Text1le Industry, A Case Study," Explorations in Entrepreneurial History, 9 (April 1957); and Glenn Porter and Harold C. Livesay, Merchants and Manufacturers (Baltimore, 1971 ).

${ }^{3}$ For a more extensive discussion of the data and the sample, see Kenneth L. Sokoloff, "Industrialization and the Growth of the Manufacturing Sector in the Northeast, 1820-1850," unpublished Ph.D. dissertation, Harvard University, 1982. The McLane Report appears in U.S. House of Representatives, Documents Relative to the Statistics of Manufactures in the U.S., 2 vols., Serial Set Numbers 222 and 223 (Washington, D.C., 1833).

${ }^{4}$ The chief problem with the valuations of fixed capital in the McLane Report is that some firms may have reported the gross or original value rather than the net. Although of some concern, the resulting overstatement of the capital values does not appear to have been severe. When dummy variables for firms established in 1830 or 1831 were included in regressions simtlar to those presented in Table 2 below, the coefficients always proved Insignificantly different from zero. Other evidence that points to the use of net value measures of the capital stock includes the comments of manufacturing establishment proprietors on their reports to the enumerators for the 1820 Census of Manufactures. Also see Robert Gallman, "How Do I Measure Thee? Let Me Count The Ways: Investment, Capital, and Wealth in the Nineteenth Century," paper presented to Caltech/Weingart conference on The Variety of 
Quantitative H1story, March 1983.

${ }^{5}$ The quoted description of the inventories to be reported by Group II firms suggests that "cash on hand" was not to be included. No adjustment for this omission has been made, but this may not be very significant as holdings of cash seem to have been modest.

${ }^{6} \mathrm{~A}$ comparison of the Group II estimates to the U.S. figures from the 1890 Census of Manufactures (which contains information on both inventories and accounts recelvable) Indicates that all of these industries except wool textiles experienced declines in their working-capital shares. For example, the share decreased from 39.5 percent to 34.8 percent in cotton text1les, and from 77.3 percent to 65.0 percent in hats. U.S. Census office, Eleventh Census of the United States: 1890. Report on the Manufacturing Industries in the United States (Washington, D.C., 1895).

${ }^{7}$ In 1850 , for example, the average number of employees per New England firm was 112.3 in cotton textiles, 37.8 in wool textiles, 7.7 in coaches/ harnesses, and 4.3 in tanning. U.S. Census Office, Abstract of Statistics of Manufactures (Washington, D.C., 1858).

${ }^{8}$ These figures may understate the value of the machinery and tools in use In some Industries, such as shoes, because employees may have worked with their own tools. No reasonable adjustment for this phenomenon seems like to alter the qualitative result.

${ }^{9}$ The qualitative results of these regressions are not sensitive to whether one includes the estimates of accounts recelvable in the total Investment and working capital figures. Regressions with estimated accounts recelvable per unit of labor as the dependent variable suggest that this component of working capital also grew more rapidly than did fixed capital with firm scale of production. The principal findings also hold if the 
regressions are estimated over the Group I firms, or if the labor Input is measured without allowing for entrepreneurial labor.

${ }^{10}$ It was evidently common practice for merchants to extend short-term loans to manufacturers and to pay for goods at some time after delivery. They frequently sold manufacturing output on commission or consignment. See Porter and Livesay, Merchants and Manufacturers, for detalls.

${ }^{11}$ See Claudia Goldin and Kenneth Sokoloff, "The Relative Productivity Hypothesis of Industrialization: The American Case, 1820-1850," Quarterly Journal of Economics (forthcoming). 